\title{
IL13RA2 wt Allele
}

National Cancer Institute

\section{Source}

National Cancer Institute. IL13RA2 wt Allele. NCI Thesaurus. Code C105973.

Human IL13RA2 wild-type allele is located within Xq13.1-q28 and is approximately $16 \mathrm{~kb}$ in length. This allele, which encodes interleukin-13 receptor subunit alpha- 2 protein, is involved in both the maturation and differentiation of B-cells. 